\title{
Hirtelen szívhalál sarcoidosis következtében
}

\author{
Sejben István dr. ${ }^{1}$ - Som Zoltán dr. ${ }^{2}$ - Cserni Gábor dr. ${ }^{1,3}$ \\ ${ }^{1}$ Bács-Kiskun Megyei Kórház, Patológiai Osztály, Kecskemét \\ ${ }^{2}$ Gottsegen György Országos Kardiológiai Intézet, Felnőtt Kardiológiai Osztály, Budapest \\ ${ }^{3}$ Szegedi Tudományegyetem, Szent-Györgyi Albert Klinikai Központ, Patológiai Intézet, Szeged
}

\begin{abstract}
Az ismeretlen eredetű, szisztémás granulomákkal járó Boeck-sarcoidosis 90\%-ban bilateralis hilaris lymphadenomegaliával és tüdőérintettséggel jár. Cardialis manifesztáció klinikailag az esetek 5\%-ában igazolható, bár a boncolt esetek 25\%-ában mutatható ki a szív megbetegedése. A cardialis elváltozás gyakran okoz atrioventricularis blokkot. A szerzők egy 44 éves férfi esetét ismertetik, aki bradycardia miatt került kivizsgálásra. Előbb másodfokú, Mobitz II-es típusú, később harmadfokú atrioventricularis blokk alakult ki. A koronarográfia ép viszonyokat jelzett. Biotronik Entovis DR típusú pacemakerbeültetés után 2,5 évvel hirtelen halál következett be. A patológiai vizsgálat cardialis, pulmonalis, lép-, vese- és nyirokcsomó-érintettséggel járó sarcoidosist talált. Fiatal és középkorú betegeknél atrioventricularis blokk megjelenése esetén célszerú egyéb ok keresése, ha a leggyakoribb coronariaeredet kizárható.
\end{abstract} Orv Hetil. 2017; 158(27): 1067-1070.

Kulcsszavak: sarcoidosis, cardialis sarcoidosis, atrioventricularis blokk

\section{Sudden cardiac death due to sarcoidosis}

\section{Case report}

Sarcoidosis is a systemic granulomatous disease of unknown aetiology, which is characterized by bilateral hilar lymphadenopathy and pulmonary disease. Clinically detected cardiac involvement occurs in $5 \%$ of sarcoid patients, although cardiac manifestations are discovered in $25 \%$ of the cases at autopsy. Sarcoid heart disease frequently causes atrioventricular block. The authors present the case of a 44-year-old man with bradycardia. On admission, second degree Mobitz II, then third degree atrioventricular block was diagnosed. Coronarography showed normal coronary arteries. 2.5 years following artificial Biotronik Entovis DR type pacemaker implantation, sudden cardiac death occurred. Autopsy revealed sarcoidosis with cardiac, pulmonary, splenic, renal and lymph node involvement. In case of young or middle-aged patients with atrioventricular block, it is best to search for other causes if the most common coronary origin can be excluded.

Keywords: sarcoidosis, cardiac sarcoidosis, atrioventricular block

Sejben I, Som Z, Cserni G. [Sudden cardiac death due to sarcoidosis. Case report]. Orv Hetil. 2017; 158(27): 1067-1070.

(Beérkezett: 2017. február 7.; elfogadva: 2017. március 7.)

A sarcoidosis ismeretlen eredetű, multiszisztémás, granulomatosus gyulladással járó betegség. A folyamat legtöbbször bilateralis hilaris lymphadenomegaliával és tüdőérintettséggel jár, de bármely szervet érinthet. A cardialis manifesztáció klinikailag az esetek 5\%-ában igazolható, bár a boncolt esetek 25\%-ában mutatható ki a szív megbetegedése [1]. Az alábbiakban egy post mortem diagnosztizált, myocardiumelváltozással járó sarcoidosist ismertetünk.

\section{Esetismertetés}

Egy 44 éves, nem dohányzó férfi beteg került a BácsKiskun Megyei Kórház Sürgősségi Betegellátó Osztályára fáradékonyság és alacsony pulzusszám miatt. Mellkasi fájdalma, eszméletvesztése nem volt. Hypertonia vagy egyéb krónikus betegség a kórelőzményben nem szerepelt. Fizikális vizsgálata során vérnyomása 150/90 Hgmm, pulzusa 42/perc volt. Az EKG másodfokú, Mo- 


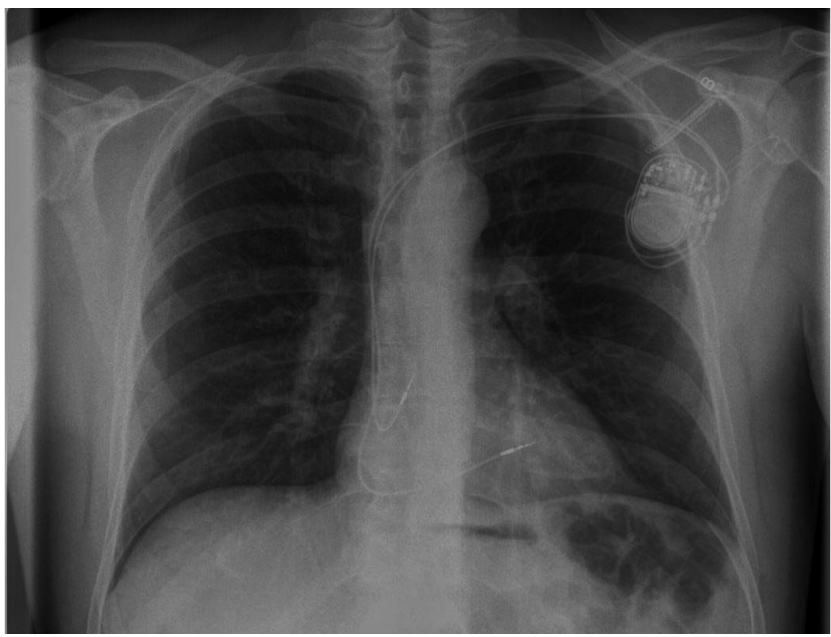

1. ábra

Anterioposterior mellkasröntgen a pacemakerbeültetést követően

bitz II-es típusú, 2:1-es atrioventricularis blokkot jelzett. A beteg a kórház invazív kardiológiai osztályára került további kivizsgálásra. Laborvizsgálata normális vérképet, vesefunkciókat, szérumion-, lipid- és glükózértékeket mutatott. A cardialis nekroenzimek szintjei a normáltartományba estek. Echokardiográfia az inferior fal mozgászavarát véleményezte, jó balkamra-funkció mellett (ejekciós frakció: 54\%). Koronarográfián az epicardialis koszorús verőér rendszere ép volt. Ezután a beteg a Gottsegen György Országos Kardiológiai Intézet Felnőtt Kardiológiai Osztályára került további kivizsgálásra, kezelésre, ahol az AV-blokk már harmadfokúvá vált, és Biotronik Entovis DR típusú, DDD módban programozott végleges pacemakerrendszer került beültetésre. A kétirányú mellkas-röntgenvizsgálat leletében tömött hilusok, a bal hilustól lateralisan és a jobb hilus alsó pólusa felett egy-egy borsnyi transzparenciacsökkenés került leírásra (1. ábra). Napi $2 \times 1,25 \mathrm{mg}$ bisoprolol és $1 \times 20 \mathrm{mg}$ famotidin terápiás javaslattal bocsátották haza. Ez után 2,5 évvel a beteg futballozás közben váratlanul összeesett, keringése, légzése leállt. Sikertelen újraélesztés után a halottvizsgálatot végző orvos az elhunyt kórboncolását kezdeményezte. Az eset feldolgozása során kiderült, hogy a beteg háziorvosánál nem járt. A pacemaker múködésével kapcsolatos gondozása a Gottsegen György Országos Kardiológiai Intézet Felnőtt Kardiológiai Osztályán történt az implantáció után egy héttel, két hónappal, nyolc hónappal és két évvel. Az ellenőrzések során a beteg minden alkalommal teljesen panaszmentes volt, a pacemaker kifogástalanul múködött. Következő megjelenése a halálát követően nem sokkal lett volna esedékes.

Kórboncoláskor a szív tömege 500 g, a bal kamra fala $15 \mathrm{~mm}$, a jobb kamráé $3 \mathrm{~mm}$ vastag volt. A szív összes ürege jelentősen tágult. A bal kamrafalban több, 1-4 cm-es szürkésfehér heges terület látszott (2. ábra). A jobb kamra falában is heges területek mutatkoztak. A koszorúerek belfelületének 10\%-át borították lumen- szúkületet nem okozó plakkok. A jobb tüdő $1070 \mathrm{~g}$, a bal 930 g tömegú volt, ami jelentős tüdővizenyôre utal. A tüdők összes lebenyében 1-5 mm-es szürkésfehér gócok látszottak (2. ábra), a zsigeri mellhártyalemezek fehéres foltozottsága mellett. A $240 \mathrm{~g}$ tömegú lépben a tüdőkben látottakkal megegyező küllemú gócok voltak (2. ábra). A $380 \mathrm{~g}$ össztömegű vesékben körülírt eltérés nem látszott. A mediastinalis és retroperitonealis nyirokcsomók makroszkóposan szabályosnak tüntek. Mikroszkóposan a szív mindkét kamrájában kiterjedt fibrosis mutatkozott gócos lymphoid infiltrátumokkal és nem necroticus granulomákkal (3. ábra). A szívizomrostok megvastagodtak. Ugyanilyen, részben koncentrikus hegesedést is mutató granulomákat találtunk a vizenyős tüdőkben (3. ábra), a lépben, valamint a makroszkóposan jellegtelen mediastinalis és retroperitonealis nyirokcsomókban. Az egyik vese is tartalmazott granulomát. Ziehl-Neelsen-, perjódsav-Schiff-, Grocott-, Gram- és Giemsa-festésekkel kórokozó nem igazolódott. Mindezek alapján cardialis, pulmonalis, lép-, nyirokcsomó- és veseérintettséggel járó sarcoidosist jelöltünk meg alapbetegségként. A necrosis és a kórokozó hiánya, a jellegzetes lokalizáció és klinikai kép az infektív granulomákat, a több szerv érintettsége pedig az idiopathiás óriássejtes myocarditist kizárta. A halál közvetlen oka heveny balszívfél-elégtelenség volt.

\section{Megbeszélés}

A világon mindenütt előforduló sarcoidosis incidenciája a skandináv országokban és Írországban a legmagasabb. Nőknél és feketéknél gyakrabban fordul elő [2]. Sarcoidosisra morfológiailag nem necrotizáló granulomatosus gyulladás (sarcoid típusú granuloma) jellemző $[3,4]$. Ritkán lehet kis necrosis a laesióban, nagyobb elhalás rendkívül ritka. A granulomákban, többnyire az óriássejtekben, Schaumann-testek, aszteroid testek, kettősen törő kristályok és Hamazaki-Wesenberg-testek lehetnek. Sem a sarcoid granulomák, sem a különböző inclusiók nem specifikusak a kórképre [4]. Szinte minden szervet megtámadhat a betegség, de egyes szervekben jóval gyakoribb. Az esetek mintegy 90\%-ában van bilateralis hilaris lymphadenopathia és pulmonalis folyamat. Szívérintettséget először Bernstein és mtsai írtak le 1929-ben [5, 6]. A cardialis manifesztáció klinikailag 5\%-ban jelentkezik, míg boncolással 25\%-ban mutatható ki [1]. Egy finn tanulmány 1988 és 2012 között a cardialis sarcoidosis gyakoriságának hússzoros növekedését találta, amit a jobb diagnosztika következményének tartott [6]. EKG, echokardiográfia, PET, cardialis MR, szívizom-perfúziós szcintigráfia és endomyocardialis biopszia segíthet a szívérintettség kimutatásában $[1,2,7]$. A sarcoidosis letalitása $1-5 \%$ közötti. Legtöbbször a tüdőfolyamat vezet halálhoz, a második leggyakoribb halálok pedig a szív érintettsége. Japánban fordított helyzetről számoltak be Iwai és mtsai, akiknél a leggyakoribb halálok a szív érintettsége volt [4]. A cardialis manifesztációval összefüggő 


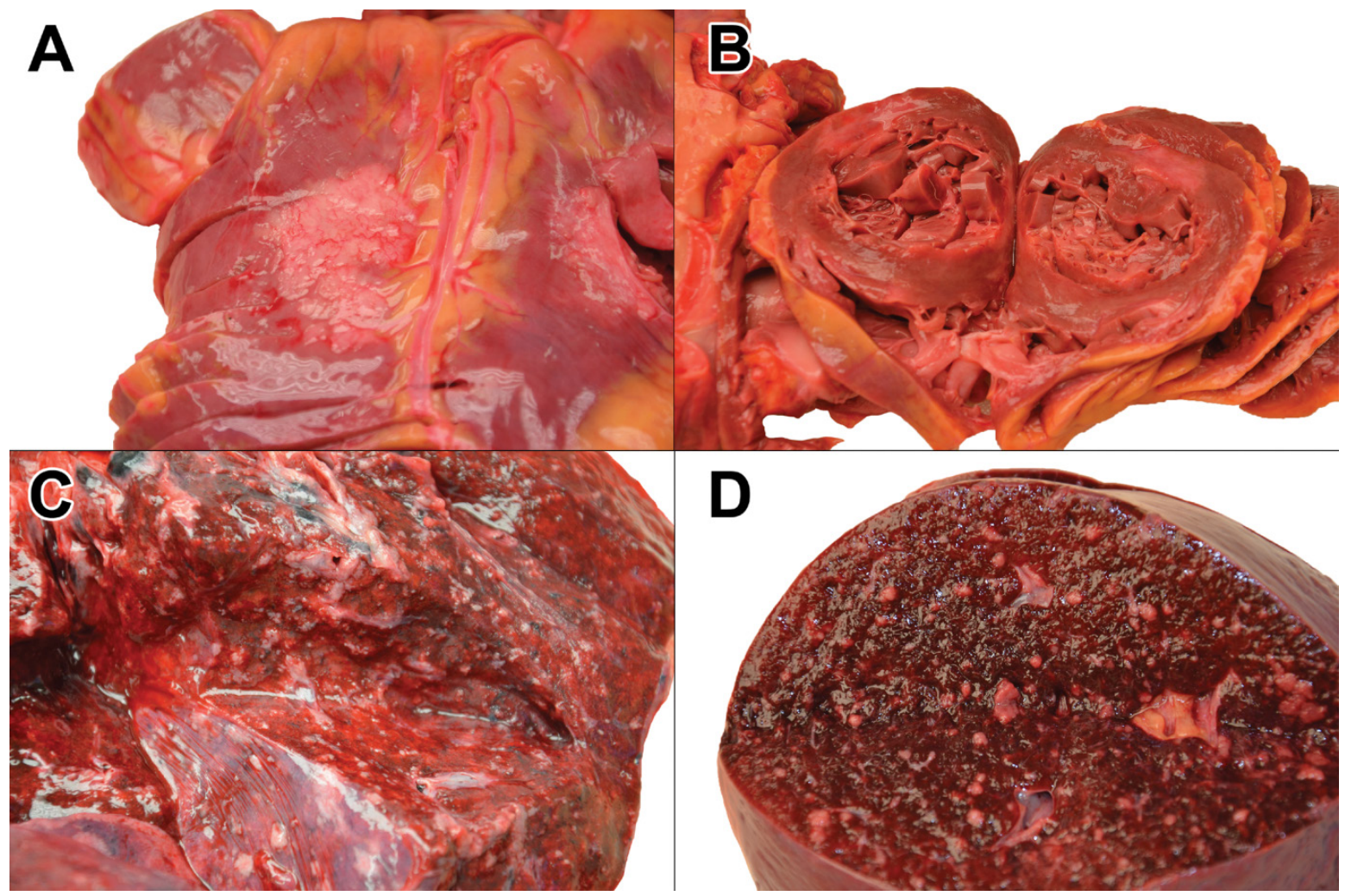

2. ábra

A sarcoidosis makroszkópos megjelenése

A A koszorús verőér hátsó leszálló ága lényegében hártyás, a pericardium szürkésfehér foltozottságot mutat. B Transmuralis hegesedés a bal kamra falában. C A tüdóben számos szürkésfehér göb (granuloma) mutatkozott, akárcsak a lépben (D)

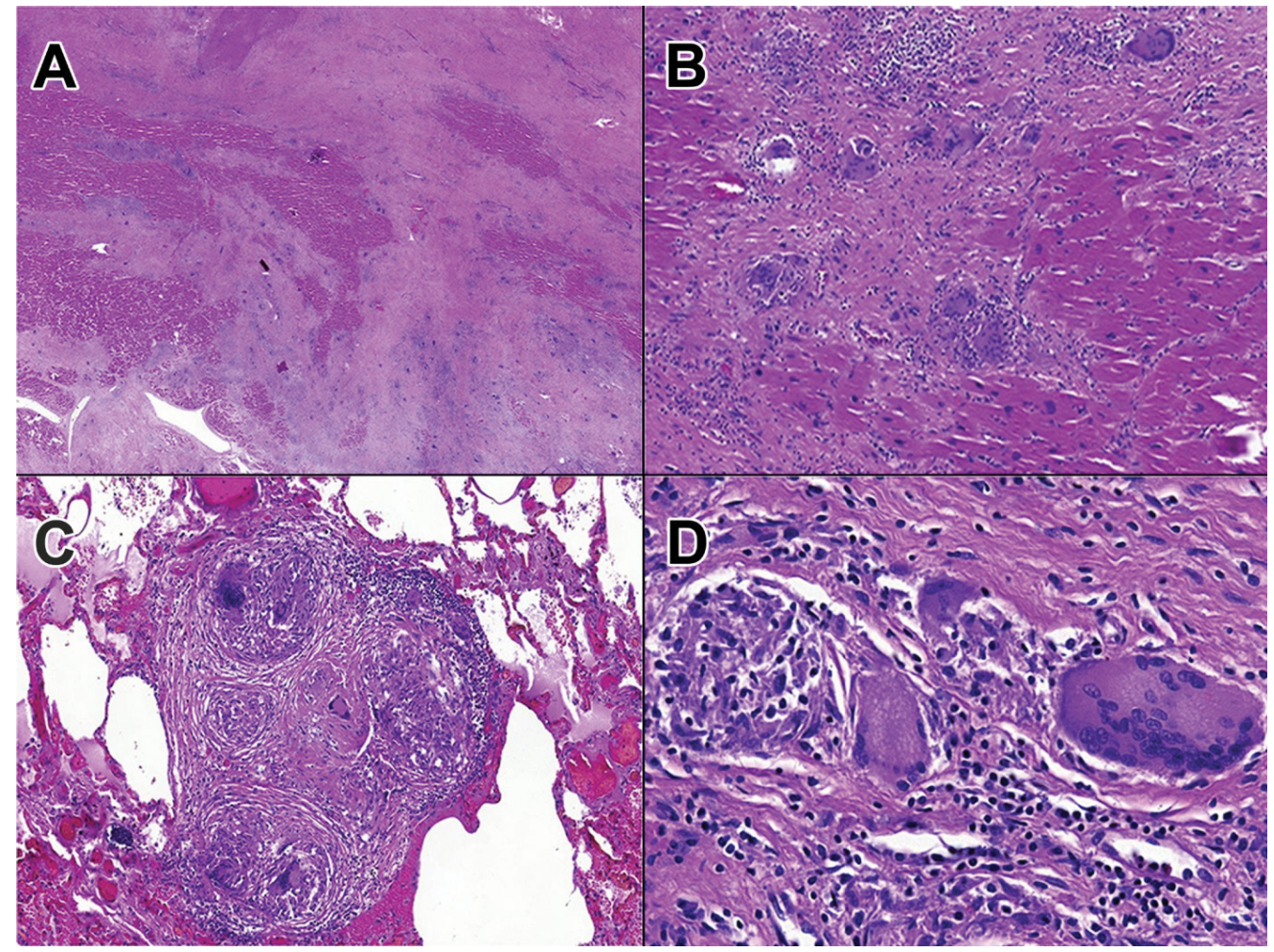

3. ábra

A sarcoidosis mikroszkópos képe

A A szívizom kiterjedt hegesedése. B Granulomák a myocardiumban. C Granulomatosus gyulladás és intraalveolaris oedema a tüdőben. D Hegesedő granuloma a szívben. Hematoxilin-eozin festés, négyszeres (A), tízszeres (B, C) és negyvenszeres (D) nagyítás 
halálozás pangásos szívelégtelenség vagy letalis ritmuszavar miatt következik be. A cardialis sarcoidosis tünetmentes kamrai diszfunkciót, pitvari vagy kamrai aritmiákat, atrioventricularis blokkot és pangásos szívelégtelenséget okozhat klinikailag. Fiatalokban az atrioventricularis blokk lehetséges oka a sarcoidosis és a Lyme-kór is. Tehát a legjellemzőbb ischaemiás eredet kizárása esetén célszerü további vizsgálatok végzése a kezelhető (például sarcoidosis) vagy gyógyítható (például Lymekór) ok kiszürése céljából. Cardialis sarcoidosis esetében nagy dózisú szteroidkezeléssel megelőzhető a szívkárosodás progressziója és csökkenthető a letalis kimenetel kockázata [2].

Esetünk azt példázza, hogy a sarcoidosis nem szokványos klinikai megjelenése nagy diagnosztikus kihívást jelent, és felhívja a figyelmet arra, hogy fiatal vagy középkorú betegekben atrioventricularis blokk megjelenése esetén célszerú egyéb ok keresése, ha a leggyakoribb arterioscleroticus eredet kizárható.

Anyagi támogatás: A dolgozatot részben a Nemzeti Kutatási, Fejlesztési és Innovációs Hivatal GINOP-2.3.215-2016-00020 számú pályázata támogatta.

Szerzői munkamegosztás: S. I.: A kézirat megszövegezése, adatgyưjjtés, irodalomkutatás. Cs. G.: A kézirat javí- tása, az ábrák elkészítése. S. Z.: A kézirat átnézése, adatgyưjtés. A cikk végleges változatát valamennyi szerző elolvasta és jóváhagyta.

Érdekeltségek: A szerzőknek nincsenek érdekeltségeik.

\section{Irodalom}

[1] Iannuzzi M C, Rybicki B A, Teirstein A S. Sarcoidosis. N Engl J Med. 2007; 357: 2153-2165.

[2] Dubrey S W, Falk R H. Diagnosis and management of cardiac sarcoidosis. Prog Cardiovasc Dis. 2010; 52: 336-346.

[3] Zsiray M, Badár É, Udud K, et al. Transbronchial needle aspiration in the diagnosis of sarcoidosis. [Transbronchialis túaspiráció a sarcoidosis diagnosztikájában.] Lege Artis Medicinae 2004; 14: 672-675. [Hungarian]

[4] Rosen Y. Pathology of sarcoidosis. Semin Respir Crit Care Med, 2007; 28: 36-52.

[5] Lagana S M, Parwani A V, Nichols L C. Cardiac sarcoidosis. A pathology-focused review. Arch Pathol Lab Med. 2010; 134: 1039-1046.

[6] Kandolin R, Lehtonen J, Airaksinen J, et al. Cardiac sarcoidosis epidemiology, characteristics, and outcome over 25 years in a nationwide study. Circulation 2015; 131: 624-632.

[7] Hulten E, Aslam S, Osborne M, et al. Cardiac sarcoidosis - state of the art review. Cardiovasc Diagn Ther. 2016; 6: 50-63.

(Sejben István dr., Kecskemét, Nyíri út 38., 6000 e-mail: sejbenist@freemail.hu)

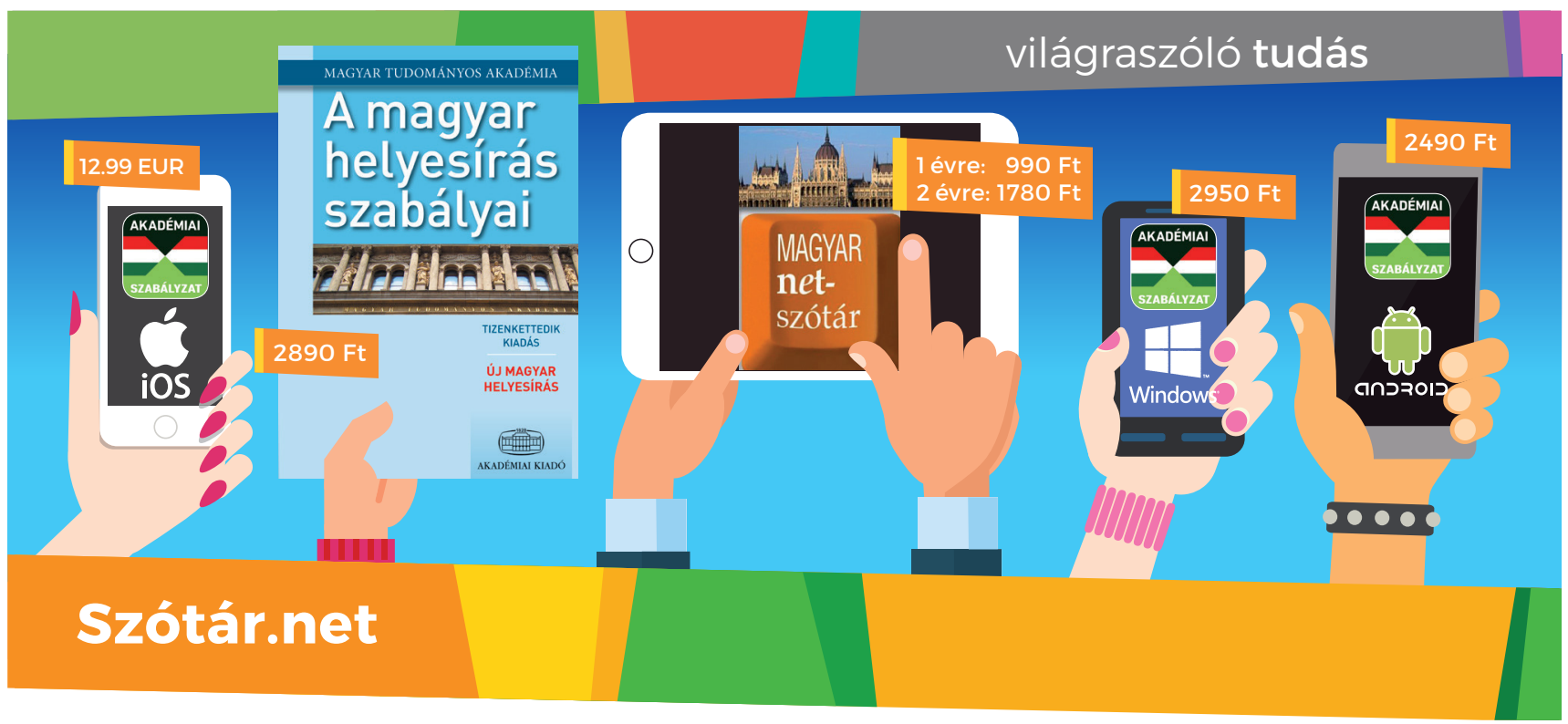

\section{A magyar helyesírás szabályai 12. kiadás}

\section{Mindig a keze ügyében!}

\begin{tabular}{l|l} 
- a Magyar Tudományos Akadémia szabályzata & $\begin{array}{l}\text { a 11. és a 12. kiadás közti különbségek } \\
\text { felsorolása, példákkal } \\
\text { - } 300 \text { szabálypont példákkal }\end{array}$ \\
- szabályzat és szótár egyben & tánutató
\end{tabular}

Keresse a könyvet a www.akademiai.hu oldalon, vagy válassza az online változatot és a mobilalkalmazást a www.szotar.net-en!
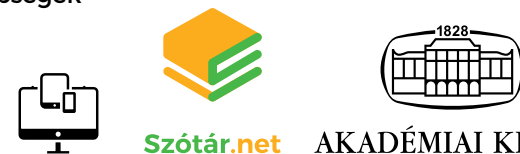

Szótár.net AKADÉMIAI KIADÓ 